\title{
Creating the Paradigm: Historical Preconditions of Modern Asatru
}

Modern Asatru, as well as the current popular appeal of 'Germanic' or 'Nordic' themes and images, are outcomes of and contributors to a discourse of Germanic myth. This discourse is related to a general tendency to conflate culture, religion and ethnicity, or to culturalize and ethnicize religion and simultaneously sacralize culture. In this chapter I argue that we can identify two prior eras, two points of crystallization, where similar tendencies were prominent and which were formative for later religious and ideological appropriations of Germanic myth: German Romanticism around 1800 and völkisch nationalism in the first third of the 2oth century.

The first formative moment was defined by the scholarship of Johann Gottfried Herder, Jacob and Wilhelm Grimm, and other intellectuals of German Romanticism. They were the first to systematize ideas about a holistic unity of natural environment, language and history located in a deep past and in rural populations. This unity and its expression in an indigenous mythological heritage were perceived as the necessary foundation for a proper nation or Volk. This Romantic constellation proved to be exceptionally malleable, productive and persistent. It influenced both cultural pluralism and exclusionist ideologies with affinities to racism and anti-Semitism. It inspired nationalist movements not only in Germany, but in Scandinavian, Anglo-Saxon and Baltic countries as well. Moreover, it provided the basis for European and North American counter-cultural movements as diverse as Anglo-Saxonism and modern witchcraft (Wicca). It is no coincidence that the years after 1900 - our second point of crystallization - have been characterized as 'neo-Romantic.' Romantic ideas about a unity of the Volk were radicalized in the German völkisch movement and turned into an alternative religion around 1910.

Thus, it seems relevant to begin our discussions of the genealogy and significance of modern Asatru by briefly introducing the main contributors (persons and organizations alike) to a discourse on Nordic myth in Romanticism, focusing in particular on the names and concepts which will reappear in the following chapters. Furthermore, in this chapter we will consider völkisch religion and the German(ic) Faith Movement, and their broader context in several nationalist and alternative movements. Finally, modern witchcraft, or Wicca, will be presented. While the latter takes up the same Romantic constellation as

(C) KONINKLIJKE BRILL NV, LEIDEN, 2016 | DOI 10.1163/9789004309517_003

This is an open-access article distributed under the terms of the Creative Commons Attribution-

NonCommercial 3.o. Unported (CC BY-NC 3.o) License, http://creativecommons.org/licenses/by-nc/3.0/ 9789004309517 
the others, due to its origin in England in the 1950s it gives the constellation a different twist. In many senses, it also contributes a more flexible framework and more malleable ritual practices, both of which prove to be important for contemporary Asatru.

\section{The Search for a National Mythology in European Romanticism}

While we can identify German Romanticism as a key formative moment for the emergence of a discourse of Germanic myth, individual elements within this influential cluster of ideas were in place already in European humanism and Renaissance thought. This era extended its interest in the mythologies of Greek and Roman antiquity to imagined national antiquities as well. German humanism contributed with a patriotic interpretation of Tacitus' Germania and Annales and established the misleading and fateful idea that the German nation was a direct descendant of the Northern tribes on the eastern side of the river Rhine, who were not subject to Roman rule and whom Julius Cesar called "Germani". ' Consequently, the traits that the Roman ethnographer Tacitus (informed by Aristotelian climate theory and contemporary stereotypes of the ethnic other) had perceived as typical for northern barbarian primitives, now appeared to the German patriots of humanism as timeless, positive national characteristics of a warrior people that:

- is hardened by a harsh climate

- is impressive in its simplicity and authenticity

- possesses a fierce sense of freedom and independence

- is faithful

- is pure

- worships nature

- venerates its women and priestesses

- is prone to excessive drinking. ${ }^{2}$

1 Cf. Dieter Mertens, "Die Instrumentalisierung der 'Germania' des Tacitus durch die deutschen Humanisten," in Zur Geschichte der Gleichung 'germanisch - deutsch.' Sprache und Namen, Geschichte und Institutionen, ed. Heinrich Beck, et al., Ergänzungsbände zum Reallexikon der germanischen Altertumskunde (Berlin: de Gruyter, 2004).

2 This version of a German ideology is discussed in depth in Klaus v. See, Deutsche GermanenIdeologie vom Humanismus bis zur Gegenwart (Frankfurt a.M.: Athenäum-Verlag, 1970). See also Barbar Germane Arier. Die Suche nach der Identität der Deutschen (Heidelberg: Universitätsverlag C. Winter, 1994). 
Swedish Renaissance scholars used the Roman scholar Jordanes' Getica (or History of the Goths, around $551 \mathrm{AD}$ ) in a similar way: as a classical witness to the greatness of the Swedish nation as the alleged homeland of the Goths. The acclaimed scholar and founder of Swedish runic studies, Johannes Bureus (1568-1652), identified the antique lost continent Hyperborea as Sweden. He then used this finding to justify prehistoric Scandinavia as mankind's oldest culture. Driven by the contemporary trend to establish Sweden's status as a great European power, the internationally celebrated Swedish historiographer, Olaus Rudbeck, took this idea even further in his 3000 page treatise Atland eller Manheim (Atlantica, 1679-1702). Both Bureus and Rudbeck, like many of their contemporaries, took a keen interest in occultism and Rosicruceanism, thus adding a spiritual and mystical notion to their speculations about the Nordic origin of culture. ${ }^{3}$

In Denmark, several simultaneous events in the middle of the 17th century spurred the Scandinavian movement of Göticism as well. In 1643, the Danish scholar Ole Worm initiated the academic investigation into the runic alphabet. In the same year, an inconspicuous manuscript was discovered by the Icelandic bishop Brynjolfr Sveinsson. It soon attracted considerable attention and was donated to the Danish king twenty years later. The manuscript contained mythological poems about Norse deities such as Odin, Thor, Frey and Freya, cosmological visions about the origin and end of the world, as well as heroic poetry related to the Nibelungen cycle. The find was all the more sensational as it treated the same mythological materials as another medieval work, the $E d d a$, authored by the Icelandic cleric, historian and politician Snorri Sturluson (1179-1241). Snorri had composed this volume as a manual for poets and skalds. Since traditional Norse poetry was based on intricate metaphorical circumscriptions, Snorri felt the need to relate the mythological basis necessary for the understanding of these poetic images, which he feared would not be accessible to Christian poets and audiences. The manuscript identified as being found here was initially (albeit falsely) believed to be the source from which Snorri had quoted the interspersed verses in his $E d d a$. Consequently, this untitled manuscript was named Edda as well. It became known as the Elder Edda, Saemundar Edda (after an alleged author) or Poetic Edda (most common today). ${ }^{4}$ As a result of this false assumption,

3 Klaus Böldl, Der Mythos der Edda. Nordische Mythologie zwischen europäischer Aufklärung und nationaler Romantik (Tübingen etc.: Francke, 2000), 19.

4 The extent to which these works contain pre-Christian mythological knowledge is disputed up until today. Both works were written in the Christian Middle Ages, more than 200 years after the Christianization of Iceland. In the case of Snorri, rather than relating "authentic" 
two lays of the Poetic Edda, the Völuspá and the Hávamál, were included when the first edition of Snorri Sturluson's Prose Edda was published in Denmark in 1665 . This edition of medieval Norse literature remained the primary source of knowledge about Scandinavian mythology throughout the entire 18th century. Its influence is palpable up until today: the two lays included from the Poetic Edda remain the most well known, and are the most quoted in Asatru contexts.

Inspired by Scandinavian scholarship, Renaissance England also developed a variety of Gothicism. 'Gothic' became a common term denoting 'Germanic', mingling with the Italian use of the word, which associated medieval architecture with the Goths. Also in the English case, this humanist appropriation of Nordic myth was driven by patriotic sentiment. It countered contemporary pejorative Italian stereotypes of the Nordic barbarian with ideas of a 'Germanic freedom.' In all cases, the North-South distinction was thus associated with anti-Catholic affects. In Germany and Scandinavia, this anti-Catholicism was informed by the respective varieties of Protestantism, ${ }^{5}$ whereas the English and English colonists in America subscribed to the idea of a pure Anglo-Saxon church along with the myth of the free nature of Anglo-Saxon political institutions (which they based on their reception of Tacitus). ${ }^{6}$

18th century Enlightenment thought contributed additional elements to the discourse of Germanic myth. The French political philosopher Montesquieu's revaluation of Aristotelian climate theory rehabilitated Northerners as industrious, inventive, honest, proud and self-confident individuals, as bearers of nations never subjugated and thus in possession of an original, natural

Pagan worldviews, his Edda gives an impressive image of medieval European imaginations of one's Pagan "ancestors'" ideas and beliefs. The case of the Poetic Edda is even more hotly debated; the age of the individual lays, as well as the materials they are based on, is estimated with great variance by different scholars. Here too, influences of, and engagement with, both classical and medieval Christian ideas are palpable and must be taken into account. Comprehensive research summaries are provided in the introductions by Ursula Dronke, The Poetic Edda: Heroic Poems (Oxford: Clarendon Press, 1969), The Poetic Edda: Mythological Poems (Oxford: Clarendon Press, 1997), and Anthony Faulkes, "Introduction," in Snorri Sturluson: Edda. Prologue and Gylfaginning, ed. Anthony Faulkes (London: Viking Society for Northern Research, 2005).

5 See Böldl, Der Mythos der Edda, 67.

6 See Allen J. Frantzen, Desire for Origins. New Language, Old English, and Teaching the Tradition (New Brunswick/London: Rutgers University Press, 1990), 31f; Reginald Horsman, Race and Manifest Destiny. The Origins of American Racial Anglo-Saxonism (Cambridge, MA: Harvard University Press, 1981), 9-12. 
freedom. ${ }^{7}$ Montesquieu's republican ideals were a significant inspiration for Paul Henri Mallet, a Swiss who served as a professor at the University of Copenhagen. In 1755, he published the first French translation of Eddic poetry in his Introduction to the history of Denmark. It was followed by a second part in 1756 under the title Monuments de la mythologie et de la poésie des Celtes et particulièrement des anciens Scandinaves (Monuments of the Mythology and the Poetry of the Celts and Particularly the Ancient Scandinavians) and soon translated into Danish, German and English. ${ }^{8}$

Renaissance and Enlightenment antiquarian approaches to the antique ethnographic and medieval mythological sources thus established Nordic or Germanic myth as an integral part of various patriotic endeavors. Holistic ideas of the late 1700 and early 1800 s finally integrated this discourse of Germanic myth with emphatic notions of an organically rooted people. The idea that such an organic unity of landscape, language and history had to be based in mythology soon posed a problem for German thinkers, as mythological sources or information about pre-Christian German religion were practically nonexistent. The assumption that language and myth were closely related, however, served as a justification for the appropriation of Scandinavian sources (written in a related language) for the (re)construction of a 'German mythology.'

The Weimar-based theologian and philosopher Johann Gottfried Herder (1744-1803) developed an elaborate, albeit contradictory theory about the uniqueness and equal worth of all the diverse peoples of the world in his four volume Ideen zur Philosophie der Geschichte der Menschheit (Ideas for the Philosophy of History of Humanity, 1784-91). He also suggested turning to Norse mythology (as it was transferred to Germany by Mallet's writings) in order to revitalize German poetry using allegedly 'authentic' sources. ${ }^{9}$

Herder's broad and notoriously unsystematic approach led to a number of internal contradictions in his work, which in turn motivated equally contradictory trajectories of reception. His writing revaluated cultural difference, promoted the equal value of vastly different cultures, and criticized the colonial

7 Gonthier-Louis Fink, "Diskriminierung und Rehabilitierung des Nordens im Spiegel der Klimatheorie," in Imagologie des Nordens. Kulturelle Konstruktionen von Nördlichkeit in interdisziplinärer Perspektive, ed. Astrid Arndt, et al. (Frankfurt a.M. etc.: Peter Lang, 2004), 8of; Böldl, Der Mythos der Edda, 27.

8 Thomas Percy's translation Northern Antiquities from 1770 was to influence the Victorian reception of Eddic literature to an immense degree. See for example Andrew Wawn, The Vikings and the Victorians. Inventing the Old North in 1gth-Century Britain (Cambridge: Brewer, 2000), 183-212.

9 Aesthetic appropriations of Germanic myth are discussed in Chapter 9. 
endeavors of the European powers of his era, even going so far as tentatively questioning Christianity's right to mission. ${ }^{10}$ At the same time, Herder's work was driven by a Christian humanism which sought to integrate this cultural diversity into a universal history of salvation in which the German Volk was assigned particularly high status. ${ }^{11}$ Simultaneously, Herder formulated negative exceptions to his tolerant and inclusive concept of equality in difference by repeating common cultural stereotypes. Gypsies and Jews were not considered proper Völker due to their lack of a homeland and were thus a potential danger to other peoples. Turks and Huns appeared as barbarians, whereas peoples exposed to extreme climates, such as Africans and Greenlanders, were attributed primitive, animalistic qualities. With this oscillatory organicist, holistic concept of a nation or Volk, Herderian thought established a field of tension that haunts relativist, holistic and organicist concepts of culture to this day, and still reverberates in the tensions between a-racist and ethnicist conceptions of Asatru today. ${ }^{12}$

10 See e.g. Maurice Olender, The Languages of Paradise. Aryans and Semites. A Match Made in Heaven, trans. Arthur Goldhammer (New York: Other Press, 1992), 37-50, on the question of mission 42.

11 For such contradictory perceptions of Herder see for example Bruce Lincoln, Theorizing Myth. Narrative, Ideology, and Scholarship (Chicago/London: University of Chicago Press, 1999), 52-54 and Zeev Sternhell, "Von der Gegenaufklärung zu Faschismus und Nazismus. Gedanken zur europäischen Katastrophe des 20. Jahrhunderts," in Die Dynamik der europäischen Rechten. Geschichte, Kontinuitäten, Wandel, ed. Claudia Globisch, Agnieszka Pufelska, and Volker Weiß (Wiesbaden: vs Verlag, 2011).

12 Herder's scholarship is debated still today. A point in case is Paul Lawrence Rose, Revolutionary Antisemitism in Germany from Kant to Wagner (Princeton, NJ: Princeton University Press, 1990) who accused him of laying the grounds for an exclusionary, antiSemitic, aggressive German nationalism and Pan-Germanism, thus preparing directly for the National Socialist regime. Others have hailed him (slightly uncritically) as the creator of a modern, non-normative, non-repressive concept of culture and aesthetics, the forerunner of an anthropological or cultural turn in the humanities. (Cf. Ulrich Gaier, "Herder als Begründer des modernen Kulturbegriffs," Germanisch-Romanische Monatsschrift 57, no. 4 (2007); Wolfgang Pross, "Herder und die moderne Geschichtswissenschaft," Germanisch-Romanische Monatsschrift 57, no. 4 (2007), and Renate Stauf, "Was soll überhaupt eine Messung aller Völker nach uns Europäern?' Der Europagedanke Johann Gottfried Herders," Germanisch-Romanische Monatsschrift 57, no. 4 (2007)). For a balanced discussion of these contradictory stances see Karol Sauerland, "'Die fremden Völker in Europa.' Herders unpolitische Metaphern und Bilder zu den höchst politischen Begriffen Volk und Nation," in Unerledigte Geschichten. Der literarische Umgang mit Nationalität und Internationalität, ed. Gesa von Essen and Horst Turk (Göttingen: Wallstein, 2000), for a comprehensive discussion of Herder's oscillating work, as well as the controversies around it, see Anne Löchte, Johann Gottfried Herder. Kulturtheorie und 
While Herder looked to Scandinavian mythology for aesthetic inspiration, the brothers Jacob (1785-1863) and Wilhelm Grimm (1786-1859) gave this search for myth a more cultural, socio-political and scientific turn. They spent their productive lives trying to reconstruct the deep roots of German identity in a pristine pre-Christian German past with the help of diverse sources, ranging from fairy tales to legal documents. ${ }^{13}$ Of their works, Jacob Grimm's Deutsche Mythologie (German Mythology) is the most critical for our context. This collection, however, cannot be separated from the others. The unity of society, its rules and laws, its aesthetic expressions and its religion was foundational for the thought of Jacob Grimm in particular, who read legal sources in a mythological manner, and examined mythology in its social aspects..$^{14} \mathrm{Jacob}$ Grimm took a twofold approach to solving the problem of lacking mythological sources. Rejecting Scandinavian sources as insufficiently cognate with the German ones, he looked for mythological remnants in various contexts: in rural folk beliefs and customs, fairy tales, place names, language etc., postulating a continuity of folk beliefs, especially in an idealized countryside from preChristian times up until his time of writing. Nevertheless, in order to make sense of what he thought to have identified as those remnants, he drew on Scandinavian sources to anchor his finds in a coherent mythology. By way of creating a unity of Germanic sources, he established the image of a coherent Germanic culture in the service of German nation building. Moreover, he contributed significantly to the appropriation of Scandinavian material for not only a German, but by way of the reception of his work, for also English and Scandinavian national ideologies. ${ }^{15}$ Like Herder before him, Grimm found the

Humanitätsidee der Ideen, Humanitätsbriefe und Adrastea (Würzburg: Königshausen \& Neumann, 2005).

13 The Grimms believed fairy tales to be much more ancient than assumed today, and to contain remnants of Pagan German mythological ideas. Legal sources were seen as remnants of an indigenous legal system opposed to the 'foreign imposed' Roman law which must have been the basis of the organization of the original German nation. The results of the brothers' endeavors were published in a number of commented collections of these alleged sources for the German national past starting with fairy tales (Kinder- und Hausmärchen, 1812-1815) and legends (Deutsche Sagen 1816-1818, 2nd ed.1865-1866), followed by grammar (Deutsche Grammatik 1819, 2. ed. 1822-1840), legal sources (Deutsche Rechtsaltertümer 1828, 2nd ed., 1854), mythology (Deutsche Mythologie (1835, 3. ed. 1854)), and finally, a comprehensive dictionary of the German language which is still in use today (Deutsches Wörterbuch 1854).

14 Wolf-Daniel Hartwich, Deutsche Mythologie. Die Erfindung einer nationalen Kunstreligion (Berlin/Vienna: Philo, 2000), 51.

15 For a critical discussion of Grimm's reconstructive method and his unacknowledged appropriation of Scandinavian material see Beate Kellner, Grimms Mythen. Studien zum 
justification for this appropriation in the linguistic proximity between the Scandinavian and German languages. As this proximity also applied to Old English, Grimm claimed Anglo-Saxon literature for his program of a renewal of national German poetry and culture as well: "Anglo-Saxon poems [...] belong to all Germany as much as to England; indeed, they belong to us more than Old Norse poems in so far as their language is closer to ours."16

Herder's aesthetic and Jacob Grimms' philological interest in Germanic myth was supplemented with yet another dimension in the late 19th century by Wilhelm Mannhardt (1831-1880). Inspired by Grimm and contemporary ethnologists, for example E.B. Tylor's thesis of 'primitive tribal cultures' survival in modern eras, he turned to contemporary German folk customs and rituals in search of remnants of pre-Christian Germanic myth in his two volume Waldund Feldkulte (Forest and Field Cults, 1875 and 1877). Together with another highly significant medium of popularization, Richard Wagner's aesthetic stage imaginations of Norse gods and heroes, ${ }^{17}$ these scholars firmly established an idealized image of a mythic national past, rooted in landscape, folk literature and customs, which was formative for the later religious reception of a discourse of Germanic myth. More importantly though, Herder, Grimm, Mannhardt and others set the standard for modern methodologies in the emerging academic disciplines of philology and folklore, as well as studies of religion. ${ }^{18}$ Although Grimm's approaches and results regarding his German Mythology and Mannhardt's ideas about contemporary survivals of ancient rituals have both since been proven wrong, their impact cannot be underestimated. ${ }^{19}$

Mythosbegriff und seiner Anwendung in Jacob Grimms Deutscher Mythologie (Frankfurt a.M.: Peter Lang, 1994).

16 From Jacob Grimm's preface to his 1840 edition of Andreas and Elene, translated by and quoted in Eric Gerald Stanley, The Search for Anglo-Saxon Paganism (Cambridge: Brewer, 1975), 13 .

17 See Chapter 9.

18 Cf. Bernhard Maier, Die Religion der Germanen. Götter - Mythen - Weltbild (Munich: C.H. Beck, 2003), 53; Hans Gerhard Kippenberg, Die Entdeckung der Religionsgeschichte. Religionswissenschaft und Moderne (Munich: Beck, 1997), 120-125.

19 Modern folklore and religious studies highlight the fact that many of the customs observed by Mannhardt are playful modifications or reversals of Christian rites. Some of them might even originate in 19th century theories inspired by Mannhardt and other scholars. Cf. e.g. Maier, Die Religion der Germanen, 53 and 85. For the use of Grimm's and Mannhardt's theories in modern Wicca see Ronald Hutton, The Triumph of the Moon. A History of Modern Pagan Witchcraft (Oxford/New York: Oxford University Press, 1999), e.g. 113. For a critique of Grimm's methods see Kellner, Grimms Mythen. 
With their emphasis on creating the German Volk by rooting it in a national mythology, Herder's and the Grimms' ideas were also formative for the emerging German cultural nationalism. Paradoxically enough, these nationalist agendas had a strong international impact. The philological method offered by the Grimms promised access to the "concealed origins, the problem of detecting pure, native culture hidden beneath layers of Christian teaching." ${ }^{20}$ Its adoption became crucial for the conceptions of pre-Christian mythology and culture in the Scandinavian countries, and - in the case of AngloSaxonism - England and America, as they all saw their roots in Germanic culture as well. The early 19th century 'discovered' Old English literature in the wake of the Grimm brothers' and other German scholars' works, hoping to recover "half-veiled remains of pagan poetry,"21 not least from Beowulf. ${ }^{22}$ Through English scholarly and literary works (especially by Walter Scott), and through the studies of leading American intellectuals in Germany, German Romanticism and Anglo-Saxonism were also dispersed throughout North America. Whereas in the English context theories of Germanic, IndoEuropean, or Aryan industriousness, adventurousness, and expansionism were used to justify colonialism, in the American case, the same features served to vindicate the westward expansion. ${ }^{23}$

In the Scandinavian countries, the reception of the German scholars' theories constituted an even greater paradox. Danish scholars and intellectuals such as Nikolai Frederik Severin Grundtvig (1783-1872) and Rasmus Rask $\left(1787^{-1832}\right)$ harshly criticized what they considered the illegitimate appropriation of Scandinavian material in the service of a German national mythology. In order to affirm a Danish tradition countering the dominant German scholarship, they simultaneously employed the self-same aesthetic and philological methods. By looking for an alliance between the Icelandic and Danish sources, they created a synthetic view of the Old Norse mythic material in Danish literature. Grundtvig's ideas in particular had a major impact on later

$20 \quad$ Frantzen, Desire for Origins, 68, cf. 62-71.

21 Stanley, The Search for Anglo-Saxon Paganism, 12.

22 Cf. ibid., 67. Beowulf consequently came to be considered an original expression of the ancient Germanic national character in both England and Germany.

23 At the end of the 19th century, such Indo-European theories constituted a "potent strain of the New Imperialism," emphasizing Anglo-Saxon supremacy and providing the foundation for the ideology of a "joint destiny" which was to secure British and American world domination. Cf. Jan Nederveen Pieterse, Empire and Emancipation. Power and Liberation on a World Scale (London: Pluto Press, 1989), $264 f$. 
Danish popular imaginations of Norse myths and tales, through their wide dispersion in the influential folk high schools initiated by him. ${ }^{24}$

A parallel attempt to renew literature through the use of Norse mythology was carried out by Swedish poets of the late Romantic era. Translations of Erik Gustaf Geijer's and Esaias Tegnér's works had a significant impact on the French and English conceptions of the Viking world. ${ }^{25}$ Their poems reconfigured the Vikings as a purifying social force, creating hope for a regeneration of the Occident from the North, downplaying their brutality and emphasizing their heroic violence, as well as their spirit of adventure and discovery. ${ }^{26}$ In the Victorian era, Anglo-Saxonism was thus vitalized with a veritable flood of images and theories on Vikings and Norsemen that were utilized for a variety of political, intellectual and aesthetic agendas. ${ }^{27}$

Herder's and Grimm's ideas also spurred an interest in folklore in the Scandinavian countries, as demonstrated by the successful recorders of fairy tales, folk tales and songs (i.e., Peter Christen Asbjørnsen and Jørgen Moe in Norway as well as Gunnar Olof Hyltén-Cavallius in Sweden). Another collector and editor whose work was eagerly received, not only in his native country of Finland but also internationally, was Elias Lönnrot. He compiled folk tales and songs into what was to become Finland's national epic, the Kalevala - a central source of inspiration for contemporary popular culture and Neopagans alike. ${ }^{28}$

Productive as they were for nation building and the development of the modern humanities, the Romantic searches for a deep past, a lost ethnic authenticity and unmediated unity as a necessary basis for contemporary national cultures have inherently problematic aspects. First and foremost, they are dependent on operations of exclusion. They tend to neglect or devalue the change, cultural mixing and blending which comes with all cultural development. At the same time, they frequently align regional differences and

24 Cf. Flemming Lundgreen-Nielsen, "Gundtvig's Norse Mythological Imagery - An Experiment that Failed," in Northern Antiquity. The Post-Medieval Reception of Edda and Saga, ed. Andrew Wawn (Middlesex: Hisarlik, 1994).

25 Cf. Wawn, The Vikings and the Victorians, 117-141.

26 Cf. Régis Boyer, "Vikings, Sagas and Wasa Bread," in Northern Antiquity. The Post-Medieval Reception of Edda and Saga, ed. Andrew Wawn (Middlesex: Hisarlik, 1994), 72f, Wawn, The Vikings and the Victorians, 99f, $176 f$.

27 Garman Lord, The Way of the Heathen. A Handbook of Greater Theodism (Watertown, NY: Theod, 2000).

28 Cf. Øystein Sørensen, "Drømmen om det storgermanske rike. Pangermanismen i Norge ca. 1850-1945," in Jakten på Germania. Fra nordensvermeri til ss-arkeologi, ed. Terje Emberland and Jorunn Sem Fure (Oslo: Humanist forlag, 2009). 
historical eras that often lie several centuries apart. ${ }^{29}$ Any definition of identity is, of course, dependent on exclusions as well as inclusions. Nevertheless, in theories of continuity of a deep past and of pure origins, these exclusions tend to turn against national minorities and often lead to the promotion of ethnic purity. Romantic constructions pitted the 'Germanic,' 'Nordic' or 'Indo-Germanic' against traditional exterior adversaries: France in the case of Germany, Germany itself in the case of Denmark and, to an extent in the case of England, ${ }^{30}$ Rome (as the embodiment of the devalued but dominant south), and with it, Catholicism in most national cases. In all cases however, it was a familiar 'interior enemy' who was targeted, the Jew. This particular Romantic anti-Semitism derogates Jews because of their alleged lack of exactly the elements that form a proper Volk according to the Romantic logic:31 rootedness in a homeland, a proper language, ${ }^{32}$ literature, and mythology. ${ }^{33}$ It is then not only the distinction between North and South - Protestant and Catholic - but rather a more or less fierce distinction between the 'Germanic,' 'Aryan,' or 'IndoEuropean' and the 'Semitic' that lies at the basis of the Romantic constellation of Germanic myth and religion. As George S. Williamson has argued, "antiCatholicism and, increasingly, anti-Semitism were not matters simply of individual prejudice or hatred (although these factors also played a role) but instead structural features of the discourse on Germanic mythology"34 - features which haunt its reception more or less overtly up until the present day. In these

29 Thus Tacitus' ethnographic account of different tribes in central Europe in the Germania from the first century, Eddic literature from 13th century Iceland, and contemporary folk customs from Germany and Scandinavia are considered expressions of the same essence and used to illuminate each other in order to form a holistic image.

3o Cf. Wawn, The Vikings and the Victorians, 99. Horsman, Race and Manifest Destiny, 38 alerts us to the fact that some English were unwilling to accept an all-pervasive GermanicNorse mystique and adhered to the idea of the superiority of the "free Anglo-Saxons." They used the Aryan or Indo-European myth to give the Anglo-Saxons a deeper past, but played down their links to other Germanic peoples.

31 For a comprehensive discussion of the varieties of Romantic anti-Semitism see WolfDaniel Hartwich, Romantischer Antisemitismus. Von Klopstock bis Richard Wagner (Göttingen: Vandenhoeck \& Ruprecht, 2005).

32 Cf. Léon Poliakov, The Aryan Myth. A history of racist and nationalist ideas in Europe (New York: Basic Books, 1974); Ruth Römer, Sprachwissenschaft und Rassenideologie in Deutschland (Munich: Wilhelm Fink Verlag, 1989); Olender, Languages of Paradise.

33 Cf. Stefan Arvidsson, Aryan Idols. Indo-European Mythology as Ideology and Science, trans. Sonia Wichmann (Chicago: University of Chicago Press, 2006).

34 George S. Williamson, The Longing for Myth in Germany. Religion and Aesthetic Culture from Romanticism to Nietzsche (Chicago: University of Chicago Press, 2004), 297. 
constructions, the alliances on the 'positive' side (i.e. assumptions about who belongs to the 'Germanic' or 'Nordic' peoples, and is thus perceived as a fellow campaigner) can vary, so that we are faced with shifting identifications (e.g., Germany and the Scandinavian countries, England and Germany, America and England), which can change according to the current political situation.

So far, we can conclude that already the earliest (re-)constructions of a Germanic pre-Christian religion are fraught with both methodological and ideological problems, which often, if not always, imply cultural imperialist as well as anti-Jewish and anti-Catholic notions. In none of these early cases, however, did the search for a national past and identity lead to genuine attempts to renew the reconstructed Pagan religion as such. Romantic endeavors saw the alleged Pagan ancestors as sources of aesthetic and national renewal, rather than as serious religious competition to the established Protestant churches.

\section{The Search for a German Religion in Fin de Siecle Germany}

The first calls to 'Germanize' religion by rejecting central parts of Christianity, and to orient a national religion toward an allegedly more authentic national mythic past appear in Germany in the latter third of the 19th century. They were motivated by a twofold lack of unity in German history: the lack of a unified nation state up until 1871, and the lack of a unified state religion, since German territories were traditionally split among Catholicism, Lutheranism and Reformed United Protestantism. No individual denomination could therefore be claimed as the faith for a Germany that was to be unified politically, as was the case with the Catholic church in post-Napoleonic France, the Anglican Church in England, or Lutheran state Protestantism in the Scandinavian countries.

The first intellectual to publicly voice the explicit need for Germany to find its own national religion was the Göttingen orientalist Paul de Lagarde (born as Paul Anton Bötticher, 1827-1891). He rejected both Catholicism, because of its internationalism, and Protestantism, which he saw as a degenerate, particularistic organization. In an era when Germany as a whole was seized by the optimism of progress after the foundation of the new empire in 1871, Lagarde deplored the materialism and the lack of an inward or spiritual unity of his country. He worked actively for a religious renewal and understood himself as the prophet of a national rebirth: a fundamental reshaping of German national politics, economy, education, and finally, religion. ${ }^{35}$

35 For a brief but comprehensive overview of Lagarde's ideas see Ina-Ulrike Paul, "Paul Anton de Lagarde," in Handbuch zur 'Völkischen Bewegung' 1871-1918, ed. Uwe Puschner, 
He envisioned the integrative, supra-denominational future religion as a Christianity purged of all influences that he saw as foreign to the German people, in particular all Jewish influence, which he claimed to have found in the teachings of Paul especially. Lagarde's anti-Semitism was not based on a biological notion of race but rather on the idea of a unity of religion and nation. Nonetheless, he employed a radical rhetoric of extinction that was to influence later German anti-Semitism, including leading National Socialists such as Alfred Rosenberg.

Lagarde's efforts to 'Germanize' Christianity were not to take effect until later in the century, when the general optimism that prevailed during the era of state foundation and industrialization gave way to cultural pessimist fears of decadence. Lagarde's ideas were taken up by Richard Wagner's son-in-law, Houston Stewart Chamberlain $\left(1855^{-1927}\right)$, who brought French race theory to Germany, in particular Comte de Gobineau's ideas about the expansion and degeneration of the white race. With his two-volume racist and anti-Semitic manifesto, Die Grundlagen des 19. Jahrhunderts (The Foundations of the Nineteenth Century 1899), Chamberlain became another guiding intellectual force for the völkisch movement and National Socialism. ${ }^{36}$ The third inspirational force for early 2oth century revivals of an alleged Germanic religion was Julius Langbehn (1851-1907), a dropout from bourgeois academic life who became immensely popular with his cultural critical manifesto Rembrandt als Erzieher (Rembrandt as Educator, 1890). He championed a new reformation toward an 'original wholeness' on the basis of Germanic art and philosophy. ${ }^{37}$

The idea of a Germanization of Christianity was followed up and further popularized by the theologian and former Lutheran minister Arthur Bonus (1864-1941). In his brochure Von Stöcker zu Naumann. Ein Wort zur Germanisierung des Christentums (From Stöcker to Naumann. A Word about

Walter Schmitz, and Justus H. Ulbricht (Munich etc.: K.G. Saur, 1996). Cf. also Friedrich Wilhelm Graf, Die Wiederkehr der Götter. Religion in der modernen Kultur (Munich: C.H. Beck, 2004), 145 .

36 Cf. Hildegard Chatellier, "Rasse und Religion bei Houston Stewart Chamberlain," in Völkische Religion und Krisen der Moderne. Entwürfe 'arteigener' Glaubenssysteme seit der Jahrhundertwende, ed. Stefanie v. Schnurbein and Justus H. Ulbricht (Würzburg: Königshausen \& Neumann, 2001).

37 Cf. Fritz Stern, The Politics of Cultural Despair. A Study in the Rise of the Germanic Ideology (Berkeley, CA: University of California Press, 1961); Bernd Behrendt, "August Julius Langbehn, der 'Rembrandtdeutsche," in Handbuch zur 'Völkischen Bewegung' 1871-1918, ed. Uwe Puschner, Walter Schmitz, and Justus H. Ulbricht (Munich etc.: K.G. Saur, 1996). Rembrandt als Erzieher reached 43 editions in its first three years. 
the Germanization of Christianity, 1896) ${ }^{38}$ Bonus called for the rejuvenation of a Christianity purged of its "Semitic" and Paulinian notions, one reconstructed with 'native' Germanic elements. ${ }^{39}$ More important for our context is the fact that he contributed to the introduction of another body of Nordic sources, the medieval Icelandic sagas, to his contemporaries, and to the then-emerging searchers for religious alternatives.

The sagas are a unique genre, codified mainly in Iceland in the late 12th and 13th century. Their most popular sub-genre, the family sagas or sagas of the Icelanders, treats the activities, politics and violent feuds of the early Scandinavian settlers in Iceland in the 1oth century. ${ }^{40}$ Their realistic style renders laconic facts and dialogues but no direct information about the colorful protagonists' emotions or motives. Therefore, the sagas were long considered to be reliable, orally transmitted documentation not only of the events depicted, but also of the cultural, social, political and legal structures of pre-Christian Iceland, and not least of its Pagan beliefs and practices. Both the Pagan content and the validity of the sagas' oral transmission have long been disputed. ${ }^{41}$ Nevertheless, around 19oo, they seemed to Bonus and many others perfect evidence of the inherently "modern", unsentimental and heroic character of the medieval Icelanders, as well as of contemporary Germans - again an example of the well-established identification of the Germans with the Germanic. Bonus was a major force behind the ambitious translation project of the Icelandic sagas, called Sammlung Thule (Thule Collection), which promised to provide a basis for the "Germanization of Christianity" and the "heroization of Christ" which he stood for. ${ }^{42}$ At the same time, the now accessible saga

38 Arthur Bonus, Von Stoecker zu Naumann. Ein Wort zur Germanisierung des Christentums (Heilbronn: Eugen Salzer, 1896).

39 Cf. Rainer Lächele, "Germanisierung des Christentums - Heroisierung Christi: Arthur Bonus - Max Bewer - Julius Bode," in Völkische Religion und Krisen der Moderne. Entwürfe 'arteigener' Glaubenssysteme seit der Jahrhundertwende, ed. Stefanie v. Schnurbein and Justus H. Ulbricht (Würzburg: Königshausen \& Neumann, 2001).

40 For an English language discussion on saga literature cf. the standard work by Carol J. Clover, The Medieval Saga (Ithaca, NY: Cornell University Press, 1982).

41 Cf. Julia Zernack, Geschichten aus Thule. Íslendingasögur in Übersetzungen deutscher Germanisten, vol. 3, Berliner Beiträge zur Skandinavistik (Berlin: Freie Unversität Berlin, 1994).

42 Cf. Lächele, "Germanisierung des Christentums"; Julia Zernack, "Germanische Altertumskunde, Skandinavistik und völkische Religion," in Völkische Religion und Krisen der Moderne. Entwürfe 'arteigener' Glaubenssysteme seit der Jahrhundertwende, ed. Stefanie v. Schnurbein and Justus H. Ulbricht (Würzburg: Königshausen \& Neumann, 2001). 
literature and the views which Bonus and other leading academics harbored about its pre-Christian context became relevant sources for the emerging Germanic Pagan groups.

It was no coincidence that the saga translations as well as the translations of Eddic literature in the Sammlung Thule were published in Eugen Diederichs' publishing house. Inspired by, among others, Langbehn and Lagarde (whose work he published and popularized), Diederichs campaigned for a "new myth born from religious forces;" ${ }^{33}$ a second Reformation and Renaissance. His neoRomantic editing program featured a syncretistic blend of works by the most diverse religious and cultural reformers, as long as they promised a contribution to a spiritual renewal, the regaining of a German cultural identity: Christian as well as völkisch Neopagan, anti-Semitic as well as Jewish, socialist as well as fascist. ${ }^{44}$

With this program, Diederichs' publishing company became the "most significant platform for the new-religious movement" of Wilhelminian Germany, ${ }^{45}$ an institutional center for a number of alternative movements that established themselves in Germany (and partly other European countries) around 1900 and in turn formed the fertile ground in which the first Germanic Neopagan groups would take root. The most important of these were the

43 "einen neuen Mythos, geboren aus religiösen Kräften." Quoted in Justus H. Ulbricht, "Wider das 'Katzenjammergefühl der Enwurzelung.' Intellektuellen-Religion im Eugen Diederichs Verlag," Buchhandelsgeschichte 76 (1996), B 112.

44 It should be noted that Diederichs never narrowed his nationalist and cultural critical impulse to a national chauvinist attitude, not even in the heated atmosphere of World War I. See “'Meine Seele sehnt sich nach Sichtbarkeit deutschen Wesens.' Weltanschauung und Verlagsprogramm von Eugen Diederichs im Spannungsfeld zwischen Neuromantik und 'Konservativer Revolution," in Versammlungsort moderner Geister. Der Eugen Diederichs Verlag - Aufbruch ins Jahrhundert der Extreme, ed. Gangolf Hübinger (Munich: Diederichs, 1996), 337. For Diederichs, his publishing house and his journal Die Tat (The Action) see also Friedrich Wilhelm Graf, "Das Laboratorium der Moderne. Zur 'Verlagsreligion' des Eugen Diederichs Verlags,' in Versammlungsort moderner Geister. Der Eugen Diederichs Verlag - Aufbruch ins Jahrhundert der Extreme, ed. Gangolf Hübinger (Munich: Diederichs, 1996); Edith Hanke and Gangolf Hübinger, "Von der 'Tat'-Gemeinde zum 'Tat'-Kreis. Die Entwicklung einer Kulturzeitschrift," in Versammlungsort moderner Geister. Der Eugen Diederichs Verlag - Aufbruch ins Jahrhundert der Extreme, ed. Gangolf Hübinger (Munich: Diederichs, 1996); Meike G. Werner, "Die Erneuerung des Lebens durch ästhetische Praxis. Lebensreform, Jugend und Festkultur im Eugen Diederichs Verlag," in Versammlungsort moderner Geister. Der Eugen Diederichs Verlag - Aufbruch ins Jahrhundert der Extreme, ed. Gangolf Hübinger (Munich: Diederichs, 1996). 
densely interwoven youth movement, life reform movement, contemporary occultism, and völkisch movement.

The German youth movement emerged from a number of independent small circles, associations and journals, amongst them the famous Wandervogel, founded in 19o1. It gathered hiking groups run by high-school students and reform-oriented teachers. For these groups, 'youth' represented a more authentic state of being, which was set against the stifled, materialistic bourgeois culture of their fathers, and could be accessed through outdoor activities and allegedly authentic, natural cultural activities such as folksong and dance. ${ }^{46}$ The youth movement never developed original political or religious ideas and was open to impulses from various directions. It took up influences from the völkisch movement from the beginning, and many of the hiking Bünde (associations) were closely intertwined with völkisch religious organizations, especially those of the non-Christian kind. ${ }^{47}$

Equally important impulses came from the life reform movement, which shared central goals with the youth movement such as an emphatic focus on 'authenticity,' 'purity,' 'beauty,' 'naturalness' and 'health.' United by such general ideals, and by a bourgeois anti-capitalism critical of blind industrial progress and urbanization gone awry, the life reform movement presented as a heterogeneous network of more or less loosely structured associations, circles, journals, businesses, publishers and individuals. Fears of degeneration were countered with an array of reform efforts regarding body and soul, concepts of nature, and various life practices. ${ }^{48}$ Among its branches were movements for

46 Cf. Frank Trommler, "Mission ohne Ziel. Über den Kult der Jugend im modernen Deutschland," in 'Mit uns zieht die neue Zeit.' Der Mythos Jugend, ed. Thomas Koebner, Rolf-Peter Janz, and Frank Trommler (Frankfurt a.M.: Suhrkamp, 1985); Winfried Mogge, "Wandervogel, Freideutsche Jugend und Bünde. Zum Jugendbild der bürgerlichen Jugendbewegung," in 'Mit uns zieht die neue Zeit.' Der Mythos Jugend, ed. Thomas Koebner, Rolf-Peter Janz, and Frank Trommler (Frankfurt a.M.: Suhrkamp, 1985). See also Uwe Puschner, "Völkische Bewegung und Jugendbewegung," in Ideengeschichte als politische Aufklärung. Festschrift für Wolfgang Wippermann zum 65. Geburtstag, ed. Stefan Vogt, et al. (Berlin: Metropol, 2010).

47 Winfried Mogge, “'Wir lieben Balder, den Lichten...' Völkisch-religiöse Jugendbünde vom Wilhelminischen Reich zum 'Dritten Reich,'” in Die völkisch-religiöse Bewegung im Nationalsozialismus. Eine Beziehungs- und Konfliktgeschichte, ed. Uwe Puschner and Clemens Vollnhals (Göttingen: Vandenhoeck \& Ruprecht, 2012).

48 Cf. Klaus Wolbert, "Die Lebensreform - Anträge zur Debatte," in Die Lebensreform. Entwürfe zur Neugestaltung von Leben und Kunst um 19oo, ed. Kai Buchholz, et al. (Darmstadt: haeusser, 2001), Diethart Kerbs and Jürgen Reulecke, Handbuch der deutschen Reformbewegungen 1880-1933 (Wuppertal: Peter Hammer Verlag, 1998). 
the protection of nature and landscape; garden settlements; the renewal of architecture and crafts; ${ }^{49}$ alternative agriculture; naturopathy and alternative medicine; reform of education, art, music, dance, clothing and nutrition; antialcoholism; nudism; social and racial hygiene; and sexual reform. As practical as individual undertakings within the movement were, some of them can be read as interventions into religious discourse as well, since all of these concepts of nature, the body, and health took on a spiritual or transcendental quality. In our context, it is important to note that the North became the location of such desired qualities as light, naturalness, youth and beauty - a fact that linked the life reform movement with equivalent movements in the Scandinavian countries, and allowed the inclusion of racial ideologies of whiteness. ${ }^{50}$ Nevertheless, the life reform movement, as with most of the alternative movements discussed in this book, was not politically unified, rather it "connected modernity and counter-modernity, enthusiasm for progress and reaction, a rational world-view and irrational eccentricity." 51

Religious or spiritual ideas within the life reform movement were based on several contemporary intellectual and popular currents that also became relevant for völkisch religion. Modern worldly conceptions of religiosity were based on 19th century theological anticlerical philosophies, historical-critical bible studies, and historical Jesus studies originating in David Friedrich Strauß' and Ernest Renan's ideas of Jesus as both a human and merely an example of an eternal divine essence of humanity. ${ }^{52}$ Another strand of influence was contemporary Darwinism, especially in the form of Monism, which the zoologist and physician Ernst Haeckel (1834-1919) promoted in the popular science foundation Monistenbund (Monist League, founded 1906). ${ }^{53}$ Vitalist philosophers such as Arthur Schopenhauer, Friedrich Nietzsche, Eduard von Hartmann and Ludwig Klages emphasized the irrational and its rejection of intellectualism and mechanism, thus providing many contemporaries with immanent,

49 This is an equivalent of the English arts and crafts movement, with which it shared motives and was connected to on many levels.

5o A spiritualization of race was particularly prominent in German nudism, which was dominated by a spirituality of the sun, light, and whiteness and quickly moved into a cult of the healthy, light Aryan body. Cf. Ulrich Linse, "Nordisches in der deutschen Lebensreformbewegung," in Wahlverwandtschaft. Skandinavien und Deutschland $1800-$ 1914, ed. Bernd Henningsen, et al. (Berlin: Jovis, 1997).

51 Wolbert, "Die Lebensreform - Anträge zur Debatte," 17: "vernetzt die Moderne mit der Gegenmoderne, die Fortschrittsbegeisterung mit der Reaktion, die rationale Weltsicht mit irrationaler Verstiegenheit."

$5^{2}$ Cf. Arvidsson, Aryan Idols, 92-96.

53 For Haeckel see Chapter 6. 
activist concepts of religion as well. Vitalism was frequently combined with racial theories attributing 'Aryans' or Germanic peoples a specific propensity for this kind of activist spirituality.

Whereas Ernst Haeckel's scientific concepts played a certain role for racial theories of an immanent religion, a spiritual version of such racial teachings was developed in several varieties of contemporary Western occultism, as in Theodor Reuss' Ordo Templi Orientis (о.т.o.), Aleister Crowley's Order of the Golden Dawn, ${ }^{54}$ and particularly in the international theosophical movement. ${ }^{55}$ As a whole, theosophy, as well as the manifold secret orders and lodges by which it was inspired and which it in turn inspired, oscillated between two poles: a liberal faction, which emphasized the unity of mankind and the hope for a New Age in which love and beauty would rule; and a racist, nationalist faction that gained more and more influence throughout the early 2oth century, and held strong connections with the European anti-Semitic movement. ${ }^{56}$ A German branch of the Theosophical Society (founded in New York in 1875, and later relocated to India) took hold around 1900 within the life reform movement, with which it shared its ambivalent political and ideological position. It attracted liberals and progressive bohemians at the alternative spiritual center at Monte Verità near Ascona, but also individuals with conservative and völkisch leanings and Wagnerians. ${ }^{57}$

54 For an overview over occult orders and secret societies in the era see Stuckrad, Western Esotericism, 113-121. For a discussion of Crowley's significance for modern Paganism in general cf. Henrik Bogdan, "The Influence of Aleister Crowley on Gerald Gardner and the Early Witchcraft Movement," in Handbook of Contemporary Neopaganism, ed. James R. Lewis and Murphy Pizza (Leiden/Boston: Brill, 2009).

55 Modern theosophy originated within the context of American spiritualism in the last half of the 19th century. It was mainly based on the writings of Helena Petrovna Blavatsky (1831-1891), a Russian-born adventuress who spent parts of her life in India, where she claimed to have had medial contact with spiritual masters who conveyed their ancient teachings to her. Combining traditional occultist elements with popularized Hinduism, Buddhism, and Darwinian evolutionary theory, Blavatsky depicted world history as a continual spiritual progress towards ever-higher spiritual spheres. See Nicholas Goodrick-Clarke, Helena Blavatsky (Berkeley, CA: North Atlantic Books, 2004), for a brief summary and for more literature on theosophy see Stuckrad, Western Esotericism, 123-132. Claiming that all religion was based on a common esoteric essence, which she 'revealed' in her books Isis Unveiled (1877) and The Secret Doctrine (1888), she imagined an intricate system of so-called "root races" and "sub races" with the "Aryans" at the very top of the scale.

56 Cf. James Webb, The Occult Establishment (La Salle, IL: Open Court, 1976), 213-222.

57 Cf. Nicholas Goodrick-Clarke, The Occult Roots of Nazism. The Ariosophists of Austria and Germany 1890-1935 (Wellingborough, Northamptonshire: Aquarian Press, 1985), 22-27. 
Within this complex conglomerate of alternative spirituality, one person stands out who was to influence later Neopaganism to a significant extent: Carl Gustav Jung, the student and collaborator of Sigmund Freud. Jung turned the focus of depth psychology from early childhood sexual trauma and fantasy to a theory of the collective unconscious, in which myths and tales were seen as foundational for the development of the human psyche. What is less well known today is the fact that he based his reflections about the collective unconscious and its archetypes on theories of land and nationhood, which he saw as foundational for psychological as well as cultural forms. He thus assigned a mythic substructure to not only individual, but also national and racial psychologies. He proclaimed a clear distinction between the 'Aryan' and the Jewish psyche. Germans and Jews thus became complementary 'nations' with complementary psychic and mythic structures. ${ }^{58}$

In their complex structures and often contradictory ideologies, the life reform and occultist movements resembled another integrative network of the era, the völkisch movement, with which they overlapped significantly. The völkisch movement was characterized by an equally confusing organizational structure, an extra-parliamentarian conglomerate of small associations, circles, journals, etc. Its ideology was far from unified, as it contained contradictory elements of anti-modernism and modernism, nationalism and pan-Germanicism,

Rudolf Steiner, a former chair of the German Theosophical Society, went on to develop his own version of theosophical thought, anthroposophy. Anthroposophy shifted the emphasis from Eastern to Gnostic-Christian spirituality and was to bring forth a number of alternative reform efforts, the most internationally well-known being biodynamic agriculture and Steiner schools. For a comprehensive recent biography of Steiner see Helmut Zander, Rudolf Steiner. Die Biographie (Munich: Piper, 2011).

$5^{8}$ For discussions of Jung's attitude towards Jews and anti-Semitism see Aryeh Maidenbaum and Stephen A. Martin, eds., Lingering Shadows. Jungians, Freudians, and Anti-Semitism (Boston/London: Shambala, 1991); for his role as a "psychologist who lent his authority to nationalism, thereby legitimizing ideas of innate psychological differences between nations" see Andrew Samuels, "National Socialism, National Psychology, and Analytical Psychology," in Lingering Shadows. Jungians, Freudians, and Anti-Semitism, ed. Aryeh Maidenbaum and Stephen A. Martin (Boston/London: Shambala, 1991), 188. In his controversial book, The Jung Cult, Richard Noll, The Jung Cult. Origins of a Charismatic Movement (New York etc.: Free Press Paperbacks, 1994) uncovered the connections between Jung and Jungianism with the völkisch movement and völkisch ideology. Jung's "post-Holocaust assault on the God of the Jewish people" (Steven M. Wasserstrom, Religion after Religion. Gershom Scholem, Mircea Eliade, and Henry Corbin at Eranos (Princeton, NJ: Princeton University Press, 1999), 177) was criticized by Martin Buber as a testimony of gnostic antiSemitism (ibid). See also Chapter 5 . 
spirituality and scientism. ${ }^{59}$ Based on an outspoken anti-Semitic and racist ideology, the völkisch movement promoted an extensive renewal or rebirth of the German people, which was to counteract the widespread fear of a 'racial,' 'cultural' and not least 'spiritual' 'degeneration.' This program of renewal was based on the German ideology discussed above, which conceived of a true Volk as a holistic, self-referential, pure, and natural organism. Ideally it was to be structured in an 'organic' feudal, medieval social order, which was antithetically set against the alleged individualism, rationalism and liberalism of Mediterranean civilization and modernity. ${ }^{60}$ (Neo-)Romantic ideals thus reappear in völkisch ideology in a radicalized and especially racialized form. The desired national and cultural renewal is founded on a program of often violent racial purification and rebirth. Völkisch protagonists objected strongly to their ideology being reduced to an exclusively anti-Semitic, pessimistic racial ideology that focused on resistance against negative cultural forces (which they certainly saw in Jewish and 'degenerate racial elements'). Their commitment to 'positive' goals, and to a cultural, mental and spiritual renewal of the German people led to the promotion of a new, positive spirituality. Thus, as Uwe Puschner has aptly remarked, religion became the "archimedic point" of völkisch ideology. ${ }^{61}$

Its promotion of a holistic or totalitarian cultural renewal and its peculiar mixture of anti-modernist and modernist elements link the völkisch movement to a larger ultra-conservative current in Germany in the early 2oth century: the Conservative Revolution. The term was coined by Armin Mohler, the most prominent post-war apologist of this heterogenous extreme rightwing movement, in an attempt to distinguish it from National Socialism proper, which many of its adherents regarded with a mixture of fascination and skepticism. ${ }^{62}$ Although it has been considered contentious due to the mythic and

59 See Uwe Puschner, Die Völkische Bewegung im wilhelminischen Deutschland. Sprache Rasse - Religion (Darmstadt: Wissenschaftliche Buchgesellschaft, 2001) for a comprehensive investigation of the völkisch movement and ideology prior to WW I. An English summary of his findings can be found in "'One People, One God, One Reich.' The 'Völkisch Weltanschauung' and Movement," German Historical Institute London Bulletin 24, no. 1 (2002).

$60 \quad$ Cf. Die Völkische Bewegung im wilhelminischen Deutschland, $92 \mathrm{f}$.

61 "Deutschchristentum. Eine völkisch-christliche Weltanschauungsreligion," in Der Protestantismus - Ideologie, Konfession oder Kultur?, ed. Richard Faber and Gesine Palmer (Würzburg: Königshausen \& Neumann, 2003), 96.

62 Mohler's seminal work on the Conservative Revolution, albeit apologetically tainted, has appeared in several editions since 1950. See for example Armin Mohler, Die konservative Revolution in Deutschland 1918-1932. Grundriss ihrer Weltanschauungen (Stuttgart:Vorwerk, 
idealizing quality Mohler's use gave it, ${ }^{63}$ the term has become established. It is useful for our purposes because it captures a central moment that is also constitutive for the völkisch religious currents discussed here. While conservatism is traditionally understood as a political movement which aims at preserving existing political, social and cultural structures, Conservative Revolutionaries are convinced that modernization has already proceeded too far, and that there is little or nothing left that is worth preserving. They conclude that what is to be preserved (a new holistic state structure, a new organic culture, and a new man) has first to be created or restored in a violent revolutionary effort which is to destroy the existing structures. These "politics of cultural despair"64 are not exclusively retrogressive or anti-modern, but combine a rejection of an allegedly 'degenerate' modernity with modernist elements in shifting combinations, which lend them their peculiar dynamic - a dynamic which, as we shall see in the following chapters, characterizes large parts of Germanic Neopaganism and its attempts at religious reform and re-creation as well.

\section{German(ic) Faith and Ariosophy in the Early Twentieth Century 65}

In the first decades of the 2oth century, a number of Germanophile religious and spiritual associations began to grow out of the contradictory amalgamation of turn-of-the-century ideas and ideologies of spiritual, national, and racial renewal. Early groups such as the Deutschbund (German Union, founded in 1894) and Deutschreligiöser Bund (German Religious Union, 1903) promoted a German Christianity. Here journals played a key role in not only spreading German religious ideas but also in establishing groups: for example, the Deutsche Erneuerungsgemeinde (German Congregation of Renewal) grew out of the anti-Semite Theodor Fritsch's journal Hammer (first published in 1902), ${ }^{66}$

1950); Die konservative Revolution in Deutschland 1918-1932. Ein Handbuch, 6. revised and expanded ed. (Graz: Ares, 2005). Historian Stefan Breuer has suggested limiting it to a much smaller faction of interwar right-wing intellectuals. Cf. Stefan Breuer, Anatomie der konservativen Revolution (Darmstadt: Wissenschaftliche Buchgesellschaft, 1993).

63 Cf. "Die 'Konservative Revolution' - Kritik eines Mythos," Politische Vierteljahresschrift 31, no. 4 (1990).

64 Stern, The politics of cultural despair.

65 This sub-chapter follows my brief outline of Germanic Faith groups found in Schnurbein, “Die Suche nach einer 'arteigenen' Religion in 'germanisch'- und 'deutschgläubigen' Gruppen."

66 Michael Bönisch, "Die 'Hammer'-Bewegung," in Handbuch zur 'Völkischen Bewegung' 1871-1918, ed. Uwe Puschner, Walter Schmitz, and Justus H. Ulbricht (Munich etc.: K.G. 
and a reading circle formed around Der Volkserzieher (The People's Educator). The latter was an influential journal, begun in 1897 by the teacher and journalist Wilhelm Schwaner, which focused on reforms in education, culture and religion (mainly in a German Christian sense). ${ }^{67}$

A number of programmatic publications in the first decade of the 2oth century suggested thinking beyond Christianity altogether, paving the way for the establishment of Germanic Neopagan groups after 1910. The first public initiative was taken in 1900 by Ernst Wachler (1871-1945), a Germanist and promoter of the open air theater movement, ${ }^{68}$ in a booklet titled "Über die Zukunft des deutschen Glaubens"69 (On the future of German faith) - "the prototype of all later 'neopagan' prophecies."70 Following Lagarde in his scathing rejection of the Jewish roots of Christianity and "the epileptic fanatic" Paul, Wachler asks: "Who knows if our natural belief, our world-view will not return? Has returned and lives amongst us."71

"Are you, German soul, not rich enough to build yourself a shrine out of your innermost being?"72 - With this question, the painter, art professor and

Saur, 1996), 358. The co-founder of Deutsche Erneuerungsgemeinde (founded in 1904) was the promoter of an Aryan "racial breeding" Willibald Hentschel.

67 Justus H. Ulbricht, "Völkische Erwachsenenbildung. Intentionen, Programme und Institutionen zwischen Jahrhundertwende und Weimarer Republik," in Handbuch zur 'Völkischen Bewegung'1871-1918, ed. Uwe Puschner, Walter Schmitz, and Justus H. Ulbricht (Munich etc.: K.G. Saur, 1996), 257-262, discusses Schwaner's significance for völkisch educational programs. See also Christoph Carstensen, Der Volkserzieher. Eine historischkritische Untersuchung über die Volkserzieherbewegung Wilhelm Schwaners, Diss. Jena 1939 (Würzburg-Aumühle: Konrad Triltsch, 1941) and Alfred Ehrentreich, "Wilhelm Schwaner (1863-1944) und die Volkserzieherbewegung," Jahrbuch des Archivs der deutschen Jugendbewegung 7 (1975).

68 The significance of Wachler and his theater reform for Germanic Neopaganism is discussed in Chapter 9 .

69 Ernst Wachler, "Über die Zukunft des deutschen Glaubens," Irminsul. Schriftenreihe für Junggermanische (eddische) Religion und Weltanschauung 44 (1930 [1900]).

70 Puschner, Die Völkische Bewegung im wilhelminischen Deutschland, 226. This fact has been largely obscured by later protagonists of the movement, who tried to downplay Wachler's significance as a key figure for the early Germanic religious movement after 1913 because of his partial Jewish descent (cf. ibid., 233).

71 Wachler, "Über die Zukunft des deutschen Glaubens," 13. "Wer weiß, ob nicht unser Naturglaube, unsere Weltanschauung wiederkehren wird? Wiedergekehrt ist und unter uns lebt?" [Emphasis in original].

72 Der Volkserzieher 6 (1907), 42f: "Bist du, deutsche Seele nicht reich genug, dir aus Ureigenstem ein Heiligtum zu bauen?". 
playwright Ludwig Fahrenkrog (1867-1952) followed suit in a couple of articles titled Germanentempel (Germanic Temple) which he published in 1907 and 1908 in Der Volkserzieher. It culminated in the suggestion to form a "German religious congregation" and fight for the official recognition of this German religion.

These appeals resulted in the foundation of the Bund fürPersönlichkeitskultur (Union for the Culture of Personality) in $1911 .^{73}$ In 1912, Ludwig Fahrenkrog, Wilhelm Schwaner and Karl Weißleder constituted the Germanisch-deutsche Religions-Gemeinschaft (Germanic-German Religious Fellowship) and consecrated the outdoor altar at Hermannstein, near Rattlar, Hessen, as a place of worship. The community aimed at "leading the German to himself", ${ }^{4}$ and hoped to offer a religious alternative on an explicitly racial basis to those who felt alienated from the Christian churches:

We however want to create a space where physical and spiritual foreign economy is excluded, that is: from our most sacred: the religion. [...] Therefore, we demand from everybody who is to be admitted a clear, unambiguous declaration, that he be Germanic. That, according to the best of his belief, no drop of blood of the yellow, black, or Jewish race is in him. ${ }^{75}$

In 1913, the group was renamed the "Germanische Glaubensgemeinschaft" (German Belief Fellowship), united with the Gesellschaft Wodan (Society Wodan $)^{76}$ and given a constitution.

73 Daniel Junker, Gott in uns! Die Germanische Glaubens-Gemeinschaft. Ein Beitrag zur Geschichte völkischer Religiosität in der Weimarer Republik (Hamburg: Verlag Daniel Junker, 2002), 47.

74 "den Germanen zu sich selbst führen".

75 "Aufruf: Was will die Germanisch-deutsche Religionsgemeinschaft?," Der Volkserzieher 26 (1912): "Wir wollen aber eine Stätte schaffen aus der körperliche und geistige Fremdwirtschaft ausgeschieden sei, das ist: aus unserem Allerheiligsten: der Religion. [...] Darum fordern wir von allen Aufzunehmenden die klare, unzweideutige Erklärung, daß er Germane sei. Daß nach bestem Wissen und Gewissen kein Tropfen Bluts der gelben, schwarzen oder jüdischen Rasse in ihm sei."

76 The background of this association is slightly obscure. In 1906, the German officer Josef Weber (alias Adolf Riemann) had published a book titled Allvater oder Jehova (Allfather or Jehova). This book, as well as a number of articles by the same author, Adolf Kroll (who went on to become a leading member of the Germanische Glaubensgemeinschaft) and Ernst Wachler in the journals Hammer and Heimdall seem to have led to 
It is not quite clear what relation the foundation of the Germanischdeutsche Religions-Gemeinschaft had with the Deutscher Orden (German Order), which was established in 1911 by another important early protagonist of the German Faith Movement, Otto Sigfrid Reuter (1876-1945). It was most probably a competing endeavor, which, however, did not preclude close connections between the organizations, or membership in both. Reuter was the director of the telegraph office in Bremen and had published a book that was much read within the völkisch movement. In Sigfrid oder Christus (Sigfrid or Christ, 1910), the hero of the Nibelungen story, Sigfrid, is celebrated as a 'light' warrior who leads through victory (Sieg) to peace (Frieden). The Deutscher Orden was soon complemented by the Deutschreligiöse Gemeinschaft (German Religious Community), an inner circle for members who had left the church officially. It was renamed as the Deutschgläubige Gemeinschaft (German Faith Fellowship) in 1914. ${ }^{77}$

A third important impulse for the spirituality, ideology and practice of German(ic) Faith came from the overtly racial esoteric version of modern occultism, which gave itself the telling name 'Ariosophy.' Like völkisch religion in general, Ariosophy originated in an extreme anti-Semitic climate, and an anti-Semitic affect lies at the basis of its philosophy. However, while the German Faith Movement was based in Northern German national Protestantism, the roots for Ariosophic thinking lie in anti-Catholic, pan-German Austrian milieus ${ }^{78}$ While German Faith can be understood as an attempt to 'Germanize' or 'Aryanize' Protestantism and certain forms of the freethinking and free-religious movement, Ariosophy, in spite of its anti-Catholic attitude,

the establishment of the Gesellschaft Wodan in 1911. The exact date of the foundation is unclear. The "Verhandlungsschrift zur Germanentagung zu Salzburg vom 29. bis 31 . Gilbharts 2034" (1921) mentions 1907 as the founding year of Wodan. However, this date cannot be verified by other sources, as it possibly refers to a different group. This leads Uwe Puschner, Die Völkische Bewegung im wilhelminischen Deutschland, 238f, and Daniel Junker, Gott in uns!, 26, to the probably more correct dating, 1911. As the Gesellschaft Wodan did not require its members to leave their official affiliations with the Christian churches, it is not always counted as a truly Pagan group.

77 Cf. also Stefan Breuer, Die Völkischen in Deutschland. Kaiserreich und Weimarer Republik (Darmstadt: Wissenschaftliche Buchgesellschaft, 2008), 95-97. Daniel Junker, Gott in uns! argues convincingly for Reuter's Deutschgläubige Gemeinschaft to have been the first major Germanic religious organization in Germany. 1912 is the founding year of two other politically active militant German-religious groups, the Reichshammerbund and the Germanenorden, the latter of which was allegedly involved in several attempted assassinations in the Weimar era.

78 Cf. Goodrick-Clarke, The Occult Roots of Nazism, 10. 
adopted Catholic ideas and traits, and can be understood as the 'Germanization' of contemporary occultism, especially theosophy. Ariosophy took one of its cues from the theories of and experiments with sexual magic that were characteristic of magical orders such as Theodor Reuss' Ordo Templi Orientis (о.т.о.) and Aleister Crowley's Order of the Golden Dawn. ${ }^{79}$ This emphasis on sexuality and fertility (both literal and magic) was shared by theosophist Max Ferdinand Sebaldt von Werth (1859-1916), who described a "sexual-religion of the Aryans, a sacred practice of eugenics designed to maintain the purity of the race." 80

Sebaldt's writings provided inspiration for the first popular author to combine occultism and theosophy with an explicitly völkisch ideology: Guido (von) List (1848-1919), an Austrian journalist and author of völkisch novels and plays, ${ }^{81}$ and an activist in numerous right-wing groups. After a temporary loss of vision in 1902, List claimed to have had visions of earlier incarnations, purported to have access to what he called the ancestral memory (Erberinnerung) of the 'Ario-Germans,' and began to 'reveal' the mystic origins of the runes and language in general. ${ }^{82} \mathrm{~A}$ number of Viennese and German dignitaries (amongst them Ernst Wachler) ${ }^{83}$ supported his theories and founded the Guido-von-List-Gesellschaft (Guido von List Society) in 1908, which promoted his ideas and financed his numerous publications. List himself never established a religious organization, except for a minuscule circle of initiates called

79 For an overview of occult orders and secret societies in the era see Stuckrad, Western Esotericism, 113-121. For a discussion on Crowley's significance for modern Paganism in general cf. Bogdan, "The Influence of Aleister Crowley on Gerald Gardner and the Early Witchcraft Movement."

8o See his two works from 1897, Wanidis and D.I.s. Sexualreligion. Cf. Goodrick-Clarke, The Occult Roots of Nazism, 51 .

81 As is the case with many religious founders and occultists, verifiable facts about List's life are rare, and speculation abounds. The most reliable summary of his life and work is still Nicholas Goodrick-Clarke's investigation into Ariosophy. Cf. ibid. For a discussion of List's literary writings see Inge Kunz, "Herrenmenschentum, Neugermanen und Okkultismus. Eine soziologische Bearbeitung der Schriften von Guido List" (Unpublished doctoral thesis, Universität Wien, 1961).

82 From then on, List claimed to be of an ancient aristocratic family. Although the claim was refuted by the Austrian authorities, List and his followers continued to use the "von" in his name. Cf. Goodrick-Clarke, The Occult Roots of Nazism, 41 . For a general discussion on concepts of a new aristocracy in the völkisch movement see Alexandra Gerstner, Rassenadel und Sozialaristokratie. Adelsvorstellungen in der völkischen Bewegung (189o1914) (Berlin: SuKuLTuR, 2003).

83 Cf. Goodrick-Clarke, The Occult Roots of Nazism, 43. 
Hoher Armanen Orden (HAO, High Armanic Order). ${ }^{84}$ However, his theories and speculations about an alleged pre-historic Ario-Germanic high culture and its secret transmission through runic inscriptions and secret societies have had a strong impact on German Faith as well as on Germanic Neopaganism worldwide.

List combined a pan-German nationalism with an interest in Romantic theories of pre-Christian ritual surviving in rural customs and heraldics. Fusing it with contemporary occultist ideas, he hoped to prove once and for all that the ancient Germans and Austrians were not uneducated Pagans, but had instead developed a superior culture that became the origin of "all Aryan cultures up until today." ${ }^{85}$ From theosophy and occultism List borrowed the pantheistic and Gnostic concept that the divine permeates the world and mankind in all their dimensions, radicalizing their implicit racist and imperialist notions into an overt racial esotericism. Peoples and races appear as stages of development, with the Germans, Aryans or Ario-Germans figured as the superior and most spiritually developed race, thereby claiming leadership over and enslavement of all others. The main purpose of the Wuotanist religion promoted by List was the preservation of the superior Aryan race and the breeding of an even higher noble race through the succession of numerous incarnations. List's most original and enduring contribution to this racially radicalized theosophic system was his claim to have found a key to the original sacred language of the Ario-Germans in the runes. In his work Das Geheimnis der Runen (The Secret of the Runes, 1908), the pioneer of völkisch rune occultism developed an intricate system of correspondences, which laid the foundation for most modern versions of rune divination. ${ }^{86}$

From his friend and collaborator, Ariosophy's second 'prophet' Jörg Lanz von Liebenfels, List borrowed some of his ideas about the "occult significance of the Templars, the Manichaean struggle between the master race (the ArioGermans) and the slave races (non-Aryans) and a theory about the original homeland of the Aryans, a vanished polar continent called Arktogäa." ${ }^{17}$ Lanz was a former Cistercian monk who went on to form his own Aryan racial order,

\footnotetext{
84 Cf. ibid., $46 f$.

85 Johannes Balzli, Guido von List. Der Wiederentdecker uralter arischer Weisheit. Sein Leben und Schaffen (Vienna etc.: Guido-von-List-Gesellschaft, 1917), 29.

86 Cf. Puschner, Die Völkische Bewegung im wilhelminischen Deutschland, 27-48. For the history of modern rune magic see Chapter 3.

87 Goodrick-Clarke, The Occult Roots of Nazism, 55 .
} 
the Ordo Novi Templi, or Order of the New Templars, around $1900^{88}$ with the goal of purifying and reviving the blond, blue-eyed, heroic god-men of the Aryan race. Lanz promoted his white supremacist ideas through völkisch and Social Darwinist journals and, from 1905 on, in his own journal Ostara, where a number of members of the Guido-von-List-Society published as well.

While List received his inspiration from folklore and archaeology, Lanz based his Aryan Christian ideas on a gnostic theology. In a number of books, most prominent amongst them his Die Theozoologie oder die Kunde von den Sodoms-Äfflingen und dem Götter-Elektron (Theozoology or the Lore about the Sodom-Apelings and the Divine Electron, 1905), he elaborated an occultist reading of the Fall. According to him, man at the moment of creation was a divine creature with highly developed electric organs, artificially bred by heavenly races, the Theozoa or Elektrozoa. Lanz gave his theories a strongly misogynist bent by claiming that the unfortunate desire of the females of this "Aryan heroic race" for racially inferior "apelings" led to the "original sin" of racial miscegenation and consequently to the loss of the Aryan electric organs used to communicate with divine entities. ${ }^{89}$ Christ's mission according to Lanz was the recreation of this heroic race, the Grail its central 'electric' symbol. ${ }^{90}$

List's and Lanz' systems proved remarkably productive within the völkisch religious movement. Some of List's students applied the 'Master's' methods of

88 Just as is the case with List, little is known about Lanz' life, as he and his followers were careful to create a legendary biography. Cf. ibid., 90-122. The most knowledgeable investigator into völkisch religion, Ekkehard Hieronimus, "Jörg Lanz von Liebenfels," in Handbuch zur 'Völkischen Bewegung' 1871-1918, ed. Uwe Puschner, Walter Schmitz, and Justus H. Ulbricht (Munich etc.: K.G. Saur, 1996) summarizes the scarce facts. According to him, the Viennese born Adolf Josef Lanz (1874-1959) entered the Cistercian monastery Heiligenkreuz in Austria around 1893 and left it for unknown reasons in 1899. However, he seems to have considered himself a Cistercian brother all his life. Wilfried Daim, Der Mann der Hitler die Ideen gab. Jörg Lanz von Liebenfels, 3. ed. (Vienna: Überreuter, 1994), whose study first appeared in 1958, loses himself in speculations about Lanz' fundamental influence on Adolf Hitler, whereas Rudolf J. Mund, Jörg Lanz v. Liebenfels und der Neue Templer Orden. Die Esoterik des Christentums (Stuttgart: Spieth, 1976) wrote an equally unreliable apologetic biography.

89 One of the shifting subtitles of Ostara illustrates Lanz' racist and anti-feminist program: Bücherei der Blonden und Mannesrechtler (Library of the Blondes and Masculinists).

9o For a comprehensive discussion of völkisch-religious Grail mysticism see Sandra Franz, Die Religion des Grals. Entwürfe arteigener Religiosität im Spektrum von völkischer Bewegung, Lebensform, Okkultismus, Neuheidentum und Jugendbewegung (1871-1945), Edition Archiv der deutschen Jugendbewegung (Schwalbach Ts.: Wochenschau-Verlag, 2009). 
intuitive association and theories of racial memory to other esoteric systems such as yoga, ${ }^{91}$ or added esoteric aspects to established antiquarian disciplines, such as historical architecture. ${ }^{92}$ These protagonists were also active in the German Faith Movement as leading members or founders of their own groups, lodges, circles and journals. ${ }^{93}$ Ariosophy thus became an integral part of German(ic) Faith throughout the 1920 .

However, it did not remain uncontested in a scene that was notoriously split amongst factions and idiosyncratic activists who each had their own personal mythology and claim to leadership. Other contested issues were the necessity of a formalized ritual and institutionalized priesthood, as well as the status of the Old-Icelandic sources. These issues played a role in the controversies between Ludwig Fahrenkrog's Germanische Glaubensgemeinschaft and Otto Sigfrid Reuter's Deutschgläubige Gemeinschaft. The latter rejected formalized religious practices along with a "cult of Wotan" based on ancient sources. ${ }^{94}$ Aside from personal competition and religious questions, contemporary social

$91 \quad$ Friedrich Bernhard Marby (1882-1966) and Siegfried Adolf Kummer (1899-?) developed exercises called rune gymnastics or rune-yoga, complete with mudras (hand positions) and runic chanting, practices which are still popular amongst Asatruers today. Cf. Goodrick-Clarke, The Occult Roots of Nazism, 161f, and Bernd Wedemeyer-Kolwe, "Völkisch-religiöse Runengymnastiker im Nationalsozialismus," in Die völkisch-religiöse Bewegung im Nationalsozialismus. Eine Beziehungs- und Konfliktgeschichte, ed. Uwe Puschner and Clemens Vollnhals (Göttingen: Vandenhoeck \& Ruprecht, 2012). For a detailed discussion of rune magic in Asatru, see Chapter 3.

Philipp Stauff (1876-1923) imagined hidden runic messages in the beams of half-timbered houses. Cf. Goodrick-Clarke, The Occult Roots of Nazism, 131 and 153-155, Gregor Hufenreuter, Philipp Stauff. Ideologe, Agitator und Organisator im völkischen Netzwerk des Wilhelminischen Kaiserreichs. Zur Geschichte des Deutschvölkischen Schriftstellerverbandes, des Germanen-Ordens und der Guido-von-List-Gesellschaft (Frankfurt a.M.: Peter Lang, 2011).

93 Rudolf John Gorsleben's (1883-1944) book Die Hochzeit der Menschheit (The Zenith of Mankind, 1930) is still read in contemporary Ariosophic and racial-religious circles. Another key figure was Lanz' publisher Herbert Reichstein (1892-1944), editor of the journal Zeitschrift für Menschenkenntnis und Menschenschicksal (Journal for the Knowledge of Man and Fate of Man). A comprehensive overview of Ariosophic activities after List can be found in Goodrick-Clarke, The Occult Roots of Nazism, 123-176.

94 The connections and controversies between the two associations and their leaders Fahrenkrog and Reuter are discussed by Uwe Puschner, "Deutsche Reformbühne und völkische Kultstätte. Ernst Wachler und das Harzer Bergtheater," in Handbuch zur 'Völkischen Bewegung' 1871-1918, ed. Uwe Puschner, Walter Schmitz, and Justus H. Ulbricht (Munich etc.: K.G. Saur, 1996), 222-262, and Junker, Gott in uns!. 
issues such as sexuality and reproduction also led to splits within the German Faith community. ${ }^{95}$

The tendency to split and form new groups was accompanied by continual attempts to (re)unite the movement and to form umbrella organizations. ${ }^{96}$ The best-known endeavor in this respect was launched in 1933 by Jakob Wilhelm Hauer (1882-1962) in the wake of Hitler and the NSDAP's rise to power. The internationally renowned Indologist and long-term activist in Germanic Faith contexts had been campaigning for years to unite all non-Christian, German religious splinter groups into one movement, and finally founded the Arbeitsgemeinschaft Deutsche Glaubensbewegung (Work Fellowship German Faith Movement). However, Hauer's ambition for his movement to become the official religion of the 'Third Reich' was quickly thwarted. A number of subgroups resigned from membership soon after the movement's foundation because they did not accept Hauer's claim to leadership, or else had their own sectarian agendas. At the same time, Hitler's power politics needed the support of the established churches and had no room for dissenting religious movements. ${ }^{97}$ In spite of the fact that völkisch religious and Aryan occult ideas

95 A case in point is Ernst Hunkel's propagation of an alternative racial breeding program inspired by Willibald Hentschel. Here, the German race was to be actively improved through the foundation of breeding settlements in which one 'pure Aryan' man was to impregnate ten women, who would then raise the children collectively in the countryside. As a consequence, Hunkel was excluded from the Deutscher Orden and the Deutschgläubige Gemeinschaft in 1923. Cf. Uwe Puschner, "Mittgart - Eine völkische Utopie," in Utopien, Zukunftsvorstellungen, Gedankenexperimente. Literarische Konzepte von einer 'anderen' Welt im abendländischen Denken von der Antike bis zur Gegenwart, ed. Klaus Geus (Frankfurt a.M.: Peter Lang, 2011).

96 Together with a number of younger Deutschgläubige, whose associations had split off from the mother organization as well, Ernst Hunkel founded the Orden der Nordungen in 1924. This order had stronger leanings toward occultism, esotericism, Ariosophy, parapsychology, and psychoanalysis and included theories of Ludwig Klages, C.G. Jung and Friedrich Nietzsche into their system of belief. A new attempt at re-uniting the split groups was launched in 1927 with the Nordische Glaubensgemeinschaft which fell apart again already in 1928 due to major disputes between the founders, Otto Sigfrid Reuter and Norbert Seibertz. A more modest endeavor to at least establish a joint working group which could represent the diverse Germanic religious scene publicly was started in 1932, the Nordisch-Religiöse Arbeitsgemeinschaft. Cf. Ulrich Nanko, Die Deutsche Glaubensbewegung. Eine historische und soziologische Untersuchung (Marburg: diagonal-Verlag, 1993), 44-49.

97 For an extensive discussion of the foundation, rise, and fall of the Deutsche Glaubensbewegung see ibid. The only English-language investigation, authored by Karla Poewe, New Religions and the Nazis (New York: Routledge, 2006), greatly overestimates 
were cultivated in certain National Socialist circles, e. g., in Hitler's 'chief ideologist' Alfred Rosenberg and his Amt Rosenberg ${ }^{98}$ as well as in Heinrich Himmler's ss, ${ }^{99}$ neither Ariosophy nor Germanic Faith groups in general gained widespread positive recognition.

The significance of the whole Germanic religious movement did not lie in the numbers of its adherents, it should be noted. Even in its heyday during the 1920s, the movement as a whole probably never had more than a couple of thousand organized members. ${ }^{100}$ However, the movement counted amongst its ranks a considerable number of journalists, writers, artists, illustrators, teachers and scholars - (mostly male) members of an intellectual middle-class who were driven by the fear of losing influence and status in modern society. They proved to be active and effective disseminators of Neopagan ideas. Their imaginations of lost and regained national and cultural greatness fell on fertile ground, especially in the urban middle classes, who were driven by similar fears and hopes in connection to the rapid modernization, industrialization and urbanization of their country. Due to their activities and ideas about the nature of a pre-Christian Germanic faith and its renewal, concepts related to

Hauer's influence on National Socialism. See also the English essay on the German Faith Movement by Wilhelm Hauer, "Origin of the German Faith Movement. An Alien or a German Faith? The Semitic Character of Christianity," in Germany's New Religion, ed. Wilhelm Hauer, Karl Heim, and Karl Adam (New York: The Abingdon Press, 1937) as well as the contemporary dissertation by Heinz Bartsch, Die Wirklichkeitsmacht der Allgemeinen Deutschen Glaubensbewegung der Gegenwart (Breslau: Ludwig, 1938).

98 The Amt Rosenberg promoted research of alleged pre-Christian cults and folklore and used it as the basis to develop non-Christian celebrations, a new German ritual tradition. Cf. Ernst Piper, “'Der Nationalsozialismus steht über allen Bekenntnissen.' Alfred Rosenberg und die völkisch-religiösen Erneuerungsbestrebungen," in Die völkischreligiöse Bewegung im Nationalsozialismus. Eine Beziehungs- und Konfliktgeschichte, ed. Uwe Puschner and Clemens Vollnhals (Göttingen: Vandenhoeck \& Ruprecht, 2012), 346, and Esther Gajek, "Feiergestaltung' - Zur planmäßigen Entwicklung eines 'aus nationalsozialistischer Weltanschauung geborenen, neuen arteigenen Brauchtums' am Amt Rosenberg," in Völkische Religion und Krisen der Moderne. Entwürfe 'arteigener' Glaubenssysteme seit der Jahrhundertwende, ed. Stefanie v. Schnurbein and Justus H. Ulbricht (Würzburg: Königshausen \& Neumann, 2001).

99 ss leader Heinrich Himmler sported an intense interest in popular völkisch historical theories and occult speculation and for a while employed the "magician" Karl Maria Wiligut (1866-1946), called "Weisthor" or "Himmler's Rasputin" who claimed to have direct access to the Aryan ancestral memory, cf. Goodrick-Clarke, The Occult Roots of Nazism, 177-191.

100 For an estimate of membership numbers in the individual groups see Nanko, Die Deutsche Glaubensbewegung. 
Germanic Neopagan religion were able to take hold in other alternative movements such as the environmental movement, as well as in the academy and, most notably, in the aesthetic imagination: in literature, theater, and music. ${ }^{101}$ Thus, German(ic) religious thought and a racialized or völkisch religion became more established in the 1920 s and 305 , and the foundation was laid for the further development of a neo-Germanic religion later on in the 2oth century.

A modest international spread of German Faith ideas already in the $1920 \mathrm{~s}$ and 30 contributed to this as well. The Deutschgläubige Gemeinschaft, for instance, established and maintained contacts in the Netherlands and Scandinavian countries through the Germanen-Ring. ${ }^{102}$ In Sweden, the cultural society Samfundet Manhem, founded in 1934, gathered sympathizers of National Socialism and held contacts with the Deutsche Glaubensbewegung through pastor Nils Hannerz. ${ }^{103}$ Hauer's ideas spread in Norway through the small National Socialist subculture, which opposed the official National Socialist party's leader Vidkun Quisling and promoted a more radically racist and anti-Semitic approach. The circle around Hans S. Jacobsen and his journal Ragnarok also fostered a racial Nordic Heathen religion inspired by Jakob Wilhelm Hauer's ideas, which the liberal theologian Kristian Schjelderup had advanced in Norway. The conspiracy theories of the Tannenberg Bund were another source of inspiration in Germany. ${ }^{104}$ This movement had been started by the psychiatrist Mathilde Ludendorff and her husband Erich, the famous World War I general. Its ideology was based on a fierce anti-Semitism, antimasonism, anti-Catholicism, and anti-esotericism, which eventually encompassed a rejection of Christianity as well. ${ }^{105}$

\footnotetext{
101 For in depth discussions see Chapters 6, 8, and 9.

102 Nanko, Die Deutsche Glaubensbewegung, 46.

103 Anders Gerdmar, "Germanentum als Überideologie. Deutsch-schwedischer Theologenaustausch unter dem Hakenkreuz," in Die völkisch-religiöse Bewegung im Nationalsozialismus. Eine Beziehungs- und Konfliktgeschichte, ed. Uwe Puschner and Clemens Vollnhals (Göttingen:Vandenhoeck \& Ruprecht, 2012). For a recent gender theoretical investigation of Mathilde von Ludendorff see Annika Spilker, Geschlecht, Religion und völkischer Nationalismus. Die Ärztin und Antisemitin Mathilde von Kemnitz-Ludendorff (1877-1966) (Frankfurt a.M.: Campus, 2013).
}

104 Cf. Terje Emberland, Religion og rase. Nyhedenskap og nazisme i Norge 1933-1945 (Oslo: Humanist forlag, 2003), "Im Zeichen der Hagal-Rune. 'Arteigene' Religion und nationalsozialistischer Aktivismus in Norwegen," in Die völkisch-religiöse Bewegung im Nationalsozialismus. Eine Beziehungs- und Konfliktgeschichte, ed. Uwe Puschner and Clemens Vollnhals (Göttingen: Vandenhoeck \& Ruprecht, 2012).

105 Cf. Bettina Amm, "Die Ludendorff-Bewegung im Nationalsozialismus - Annäherung und Abgrenzungsversuche," in Die völkisch-religiöse Bewegung im Nationalsozialismus. Eine 
The Ludendorffs were also one of the many sources of inspiration for Alexander Rud Mills (1885-1964), who was responsible for transferring Germanic Neopagan ideas into an Anglo-American context. The Australian lawyer had traveled extensively in Europe between 1932 and 1935 and established contacts with British and German National Socialists. Driven by sympathies for National Socialism and a conviction of traditional Anglo-Saxon supremacy, he founded the Anglecyn Church of Odin in the 193os and published his ideas of a racial, anti-Semitic and anti-Christian religion in his main work, The Odinist Religion. Overcoming Jewish Christianity (1939).106 In the same year, a Commonwealth investigation was launched against him. He was briefly interned in 1942, partly because of his membership in the nationalist and racist movement Australia First, but mostly because he had a "fanatical regard for the German Nazi system and an equal hatred of the Jews." ${ }^{107}$ Post-war attempts to establish the First Church of Odin bore equally scant results as his first attempt at founding a church, but as we shall see, his written legacy was to influence modern Odinism significantly. ${ }^{108}$

\section{Post-War Revivals ${ }^{109}$}

The very limited efficacy of Germanic Faith and Ariosophic groups in Germany between 1933 and 1945 had a paradoxical effect on the further development of Germanic Neopaganism in the 1950 s and 6os. On the one hand, the organizational structures of neo-Germanic groups were largely destroyed, the membership reduced to a few faithful individuals, and völkisch ideology in general discredited. On the other hand, in West Germany, völkisch religious groups were able to profit from the fact of their persecution and re-organize under the protection of the constitution, which granted freedom of religion.

Beziehungs- und Konfliktgeschichte, ed. Uwe Puschner and Clemens Vollnhals (Göttingen: Vandenhoeck \& Ruprecht, 2012).

106 Alexander Rud Mills, The Odinist Religion. Overcoming Jewish Christianity (Melbourne: Ruskin Press, 1939).

107 Peter Henderson, "Frank Browne and the Neo-Nazis," Labour History 89 (2005).

108 Cf. Kaplan, Radical Religion in America, 15f; Gardell, Gods of the Blood, 167-170. See also the website for the Odinic Rite Australia which hails Rud Mills as one of their prophets and provides information on his life and work: http://www.reocities.com/osred/Rud_Mills _Brief_Biography.htm (last accessed March 03, 2014).

109 The following section is based on my article about the revival of Germanic Neopaganism in post-War Germany: Schnurbein, "Transformationen völkischer Religion seit 1945." 
Thus, the remaining members of the Ariosophic Guido-von-List-Gesellschaft continued their activities immediately after 1945 based on the 1936 statutes. Already in 1951, Wilhelm Kusserow had founded the Artgemeinschaft ${ }^{110}$ as a continuation of the Nordische Glaubensgemeinschaft, which had split-off from the Deutschgläubige Gemeinschaft in 1927. In 1957, the Deutschgläubige Gemeinschaft was re-established as well, and in the same year, Hermann Musfeldt founded the Goden-Orden, championing a race-based Ariosophy-inspired religion. ${ }^{111}$

Leading members of the Deutsche Glaubensbewegung, including its founder Jakob Wilhelm Hauer, gathered into two organizations after 1945:112 the Deutsche Unitarier Religionsgemeinschaft (German Unitarian Religious Community, DUR) ${ }^{113}$ and the Freie Akademie (Free Academy). ${ }^{114}$ Whereas the $D U R$ was a free-religious organization, the Freie Akademie fashioned itself as an academic institution with the goal of (re-)establishing the study of religion. Together with the aforementioned religious groups, these cultural organizations played an integral role as communicative centers where organized right-wing extremism was able to re-group. Here, central ideas of the so-called New Right were conceived - a movement which in turn harked back to the Conservative Revolution rather than to National Socialism and

110 The term is hard to translate into English. In German, "Art" is a biological term meaning 'species' and has been used to avoid the term 'race.' 'Artgemeinschaft' thus refers to the community of our kind, our nature, our ways, or, in fact, our race.

111 For an account of the early history of the Goden-Orden see their journal Die kosmische Wahrheit. Kosmisch-religiöse Blätter zur Pflege persönlichen Lebens [The Cosmic Truth. Cosmic-Religious Papers for the Cultivation of Personal Life], here no. 10 (1964), 4.

112 The post-war regrouping of the former Deutsche Glaubensbewegung is outlined in Ulrich Nanko, "Religiöse Gruppenbildungen vormaliger 'Deutschgläubiger' nach 1945," in Antisemitismus, Paganismus, Völkische Religion - Antisemitism, Paganism, Voelkisch Religion, ed. Hubert Cancik and Uwe Puschner (Munich: K.G. Saur, 2004).

113 For an account of the German branch of the Unitarian faith, which took a very different path than its liberal North American counterpart, see Wolfgang Seibert, Deutsche Unitarier-Religionsgemeinschaft. Entwicklung, Praxis und Organisation (Stuttgart: QuellVerlag, 1989). Seibert takes an apologetic stance and does not mention the connections between the DUR and right-wing extremism in Germany. Peter Kratz, Die Götter des New Age. Im Schnittpunkt von 'Neuem Denken,' Faschismus und Romantik (Berlin: Elefanten Press, 1994), on the other hand, is able to trace these connections, however his analysis of the ideological connections is too simplistic and overly influenced by his own anti-fascist ideology.

114 Cf. Ulrich Nanko, "Von 'Deutsch' nach 'Frei' und zurück? Jakob Wilhelm Hauer und die Frühgeschichte der Freien Akademie," in Das evangelische Württemberg zwischen Weltkrieg und Wiederaufbau, ed. Rainer Lächele and Jörg Thierfelder (Stuttgart: 1995). 
the 'old right' and which emerged at the end of the 196os in France and Germany. ${ }^{115}$

Another important area in which right-wing extremists re-grouped and networked after 1945 were youth organizations such as the Wiking Jugend (Viking Youth) from $195^{2}$ or the Bund Heimattreuer Jugend (League of Homeland Loyalist Youth, $B H J$ ), a völkisch nationalist organization which based itself on the ideals of the youth movement. ${ }^{116}$ They provided a forum which not only recruited amongst the younger generation, but where later leaders of the völkisch religious scene of the 1970s also gained their first experiences and contacts. ${ }^{117}$

115 Cf. Dudek and Jaschke, Entstehung und Entwicklung des Rechtsextremismus, 1, 42. For a discussion of the New Right and its intertwinement with modern Asatru see Chapter 4. Amongst the organizations is the Deutsches Kulturwerk europäischen Geistes (German Cultural Society of European Spirit, $D K E G$ ) founded in 1950 by the former National Socialist cultural functionary Herbert Böhme, who was involved in the foundation of the NPD, the German right-wing party. The DKEG was closely connected to the $D U R$ and was unique in its ability to gather authors tainted by their involvement in National Socialist politics under allegedly apolitical goals. (cf. Kratz, Die Götter des New Age, 294, Dudek and Jaschke, Entstehung und Entwicklung des Rechtsextremismus, 1, 44-47). The Gesellschaft für freie Publizistik (Association for Free Journalism, GfP) was able to strengthen the contacts of the $D K E G$ and other cultural and religious organizations to right-wing publishing houses (cf. ibid., 47-50). The Weltbund zum Schutz des Lebens (World League for the Protection of Life, WSL), founded in 1958, and its conference center, Collegium Humanum in Vlotho, have been important links between this scene of cultural right-wing extremism and the green movement as well as anthroposophical circles, especially during the time when Georg Werner Haverbeck was its chairman (cf. Reinhard Opitz, Faschismus ud Neofaschismus, 2 vols., vol. II (Neofaschismus in der Bundesrepublik) (Cologne: Pahl-Rugenstein, 1988), 53; Raimund Hethey and Peter Kratz, In bester Gesellschaft. Antifa-Recherche zwischen Konstervativismus und Neo-Faschismus (Göttingen: Die Werkstatt, 1991), 128-135; Kurt Hirsch, Rechts von der Union. Personen, Organisationen, Parteien seit 1945. Ein Lexikon (Munich: Knesebeck \& Schuler, 1989), 165; Volkmar Wölk, Natur und Mythos. Ökologiekonzepte der 'Neuen' Rechten im Spannungsfeld zwischen Blut und Boden und New Age, Natur und Mythos ed. (Duisburg: Diss-Texte, 1992), 6-19.) See also Chapter 6.

116 Hirsch, Rechts von der Union, 13of; Dudek and Jaschke, Entstehung und Entwicklung des Rechtsextremismus, 1, 436-480. The national and international networking of right-wing extremists with the help of cultural organizations, publishing houses and journals is also discussed at length in Gert Heidenreich and Juliane Wetzel, "Die organisierte Verwirrung. Nationale und internationale Verbindungen im rechtsextremistischen Spektrum," in Rechtsextremismus in der Bundesrepublik. Voraussetzungen, Zusammenhänge, Wirkungen, ed. Wolfgang Benz (Frankfurt a.M.: 1989).

117 Both Collegium Humanum, the Heimattreue Deutsche Jugend, a split off from the BHJ and the Viking Jugend have come under the scrutiny of the German Federal Agency for 


\section{Witchcraft and the Celtic Revival}

As important as the German völkisch forerunners are for contemporary Asatru, the stigma connected to them posed a major obstacle for the post-war expansion and renewal of Germanic Neopaganism. Another wave of esoteric and occult Neopagan revival, the Wicca movement, or witchcraft, which started in England in the 1950s and gained momentum in the 1970s, helped shift general attitudes toward such revivals and indirectly also influenced Asatru. Like Germanic Neopaganism, Wicca has its roots in 19th century European attempts to reconstruct ancient, pre-Christian religions. ${ }^{118}$ Although non-Anglo-Saxon in its orientation, it emerged from a mixture of 19th century sources very similar to that of neo-Germanic faith in Germany: English and German fictional accounts of Greek, Roman, Oriental, and also Druidic and Norse religion and scholarly studies. These in turn were employed by occultists and mysticists, culminating in Helena Petrovna Blavatsky's theosophy, which combined scholarly claims with religious revelation. In England, these Romantic images were combined with Enlightenment ideas of joyous, liberationist, and life-affirming (Germanic) Pagans - a strand of thought that also influenced German Faith groups, especially through the mediation of liberal 19th century freethinkers. ${ }^{119}$ Wicca's 'invention' of an ancient European earth goddess and her companion, the horned god (Pan), can be interpreted as the result of collaboration between poets and scholars. What scholars like Johan Jakob Bachofen, Sir Arthur Evans, Jane Ellen Harrison or James Frazer configured as ancient matriarchies and erotic rites of fertility were in fact projections back in time to what poets had imagined earlier. ${ }^{120}$ This type of 'collaboration' between fiction writers and scholars continued into the 2oth century, involving authors such as Rider Haggard, Rudyard Kipling, Richard Yeats, D.H. Lawrence and Dion Fortune, who then inspired scholars such as Robert Graves and Margaret Murray. Masonic orders and their European occultist successors (e.g., the Rosicrucians, theosophy, and the Order of the Golden Dawn) provided Wicca with a pattern of ritual and organization. ${ }^{121}$

National Security (Bundesamt für Verfassungsschutz) in recent years. Cf. for example http://www.spiegel.de/politik/deutschland/o,1518,616421,oo.html, last accessed October 19, 2011.

118 The most extensive study of the Wicca movement's inception and pre-history in the 19th century has been offered by Ronald Hutton in The Triumph of the Moon. This brief sketch is mainly based on this work.

119 Cf. ibid., 21f.

120 Cf. ibid., 39, and 43ff.

121 Cf. ibid., Chapter 4. 
Three lay scholars are of crucial importance to the blending of 19th century academic thought (mostly folklore and anthropology) with the popular folk belief in witches, and thus making them directly involved in the formation of modern witchcraft. The oldest of them, Charles G. Leland (1824-1903), had been directly exposed to the emergent discipline of folklore (Volkskunde) in Germany in the mid-19th century and to contemporary radical nationalist ideas. All of these influences were merged in his most influential work, Aradia; or the Gospel of the Witches (1899). ${ }^{122}$ Also Margaret Murray (1862-1963), a trained Egyptologist, attended lectures at German universities. There she was influenced by theories of 'survivalism' of ancient rites in folklore and customs which had been taken from Mannhardt and developed by James Frazer, the famous initiator of the myth-ritual school in religious studies and theorist of magic. ${ }^{123}$ Murray's book The Witch Cult of Western Europe (1921) gained some scholarly response and spawned an impressive popular enthusiasm. ${ }^{124} \mathrm{Her}$ idea that the people burned as witches in early modernity were actually practitioners of an ancient European fertility cult inspired the British civil servant and hobby-folklorist Gerald Gardner to claim that he had been initiated into ancient rites by English witches, which he now, breaking his oath of secrecy, revealed to the English public. Murray's theories are largely refuted and it is by now widely acknowledged, also in Wiccan circles, that Gardner's claims to authenticity are not based on reality (he constructed his own religion out of books and the practices of secret orders such as the Hermetic Order of the Golden Dawn and the Ordo Templi Orientis). ${ }^{25}$ Nevertheless, Gardner's and his later followers' (re-)construction of the alleged witches' rituals led to the formation of a broad movement. Throughout the 1970 s and 8 os it branched into various subgroups with vastly differing ideas about politics, sexuality and gender, ranging from conservative, male-oriented covens to the progressive, feminist earth-centered Reclaiming Witches around Starhawk in the San Francisco Bay Area. ${ }^{126}$

122 Cf. Sabina Magliocco, Witching Culture. Folklore and Neo-Paganism in America (Philadelphia: University of Pennsylvania Press, 2004), 44f.

123 Cf. ibid., 42f, Susanne Lanwerd, Mythos, Mutterrecht und Magie. Zur Geschichte religionswissenschaftlicher Begriffe (Berlin: Dietrich Reimer, 1993), 112-146.

124 Cf. Magliocco, Witching Culture, 47.

125 Hutton demonstrates this in detail, and at the same time emphasizes the "extraordinarily novel" form of religion which "concealed innovation under a language of continuity and restitution." Hutton, The Triumph of the Moon, 236.

126 For a still-valid comprehensive description of the various strands of Wicca and other Neopagan groups in America, see Margot Adler, Drawing Down the Moon. Witches, Druids, Goddess-Worshippers, and Other Pagans in America Today 4. ed. (New York: Penguin, 2006 
We can conclude that the basis for the emergence of modern witchcraft in England is a similar mix of Romanticist thought, nationalism, fictional literature and anthropological theory as in the case of the German scene. ${ }^{127}$ Moreover, a number of the major thinkers and inventors of this fictional ancient religion were influenced by German thought. There are other parallels as well. In both the English and the German case, adherents of the new pagan religions express alienation from and reject the dominant social order, the particular form their national state has taken. In both cases, there is also a tendency to identify with a defeated idealized group of the historical past (the ancient Germans or the ancient Celts). In the course of such operations, a number of significant dichotomies were invoked: dogmatic belief was rejected in favor of ritual, the cognitive mind in favor of the body and sexuality, the alienated in favor of authenticity, discourse in favor of imagination - and at times, and more so in Wicca than in the outspokenly masculinist German and Anglo-Saxon ideologies - the masculine in favor of the feminine. The main bearers of these movements were middle-class or lower middle-class male intellectuals fearing a loss of influence and status in capitalist and commercialized modernity.

This counter-cultural search for 'authentic' roots, the interest in the creation and execution of new rituals and the organization either in secret orders or in other small initiatory groups facilitated exchanges and sympathetic meetings between English and German forerunners of today's Neoaganism. Nonetheless, the significant differences between the revival of witchcraft in England and attempts to create a German(ic) faith in Germany should not be overlooked. The adherents of modern witchcraft had no interest in creating a new state based on a new (old) religion. Their agenda was less nationalist and more counter-cultural, whereas the German movement took a radical nationalist position from the beginning. The reasons for this can probably be found in the very different situations the two states were in. Britain was a proud imperial power at the time, held up partly by a strong Anglican and Presbyterian state church. The political problems were related to inner differences between several groups, such as the English, the Scots, the Welsh, the Irish etc. Moreover, the political fears of middle-class individuals were mostly related to a loss of imperial power, and later on, a nostalgic mourning for its loss. As has been demonstrated, in Germany, the creation of a nation state and a national religion was of eminent importance for leading intellectuals and had been so for most of the 19th century.

[1979]). For an account of Reclaiming Witches in San Francisco see Salomonsen, Enchanted Feminism.

127 See also Magliocco, Witching Culture, 5 . 